\title{
SCREEN PRINTED ELECTRODE OF CARBON NANOTUBES MODIFIED WITH GOLD NANOPARTICLES FOR SIMULTANEOUS DETERMINATION OF ZINC, LEAD AND COPPER
}

\author{
JUAN C. M. GAMBOA* \\ Universidad de Tarapacá EIEE, Av. 18 Septiembre \#2222, Arica, Chile.
}

\begin{abstract}
Differential pulse anodic stripping voltammetry, method used for simultaneous determination of zinc, copper and lead with screen printed electrode of carbon nanotubes modified with gold nanoparticles was investigated. The results indicate that a simultaneous identification and quantification of zinc, lead and copper is possible at $-0.6 \mathrm{~V},-0.26 \mathrm{~V}$ and $0.16 \mathrm{~V}$ respectively. The maximum current was linearly dependent on the concentration of $\mathrm{Zn}^{2+}, \mathrm{Pb}^{2+}$ and $\mathrm{Cu}^{2+}$, thus allowing the construction of analytical curves, being: - Ip $(\mathrm{A})=0.08+0.214\left[\mathrm{Zn}^{2+}\left(\mathrm{g} \mathrm{L}^{-1}\right)\right]$ in a range of 9.9 to $120 \mu \mathrm{g} \mathrm{L}^{-1}$ with an $\mathrm{R}^{2}=0.993 ;-\mathrm{Ip}(\mathrm{A})=-1.06+0.240\left[\mathrm{~Pb}^{2+}(\mu \mathrm{g} \mathrm{L}\right.$ $\left.\left.{ }^{1}\right)\right]$ in a range of 9.9 to $120 \mu \mathrm{g} \mathrm{L}{ }^{-1}$ with an $\mathrm{R}^{2}=0.998$; $-\mathrm{Ip}(\mathrm{A})=-10.93+15.16\left[\mathrm{Cu}^{2+}\left(\mu \mathrm{g} \mathrm{L}^{-1}\right)\right]$ in a range of 0.99 to $12 \mu \mathrm{g} \mathrm{L}^{-1}$ with an $\mathrm{R}^{2}=0.998$. The limits of detection and quantification were estimated between $1.0-3.5 \mu \mathrm{g} \mathrm{L}^{-1}$ for $\mathrm{Zn}^{2+}, 1.5-5.0 \mu \mathrm{g} \mathrm{L}^{-1}$ for $\mathrm{Pb}^{2+}$ and $0.1-0.33 \mu \mathrm{g} \mathrm{L}^{-1}$ for Cu $\mathrm{Cu}^{2+}$. An integral, selective and reliable system for simultaneous determination of heavy metals was achieved, which may have applications in field monitoring for environmental use and public health.
\end{abstract}

Keywords: Gold Nanoparticles, Screen-Printed Electrode, Carbon Nanotubes.

\section{INTRODUCTION}

The difficulty and requirement of performing in situ analysis of heavy metals in environmental samples is quite necessary for decision-making in real time.

Water is a vital element for the human being, however excessive use of water may cause a sustainable damage to the protection of the environment. Industrial growth versus water as an alimentary product indicate that finding quick response control methodologies to estimate degree of control, toxicity, or pollution of this matrix is essential.

Lead has been one of the most studied environmental and industrial toxics in the last decades. Since, at low concentrations, children suffer considerable effects due to the exposure of this element causing behavioral problems, learning disability, among others. Several studies of environmental health have demonstrated that children exposed to this metal, due to the industries as emission sources and contaminated soils, may suffer severe damages. Lead exposure in workers may cause adverse effects to nervous system, kidneys and blood (hemoglobin) ${ }^{1-4}$.

Therefore, The World Health Organization (WHO) recommends that lead levels in drinking water not exceed $0.1 \mathrm{mg} \mathrm{L}^{-15}$.

Copper is an element that occurs naturally in the environment, mainly due to rock weathering and volcanic activity. Furthermore, this element is an essential nutrient for humans, it means that copper deficiency may result in anemia or skeletal malformations. However, prolonged exposure to high concentrations of copper may turn it into a toxic element. Important anthropogenic sources include the smelting process within the mining industry due to the processing of such element.

Moreover, copper is being used in the process of water treatment for algae control. On the other hand, one of the main entry routes of copper to human beings is through drinking water, whose via or source is related to copper pipe corrosion from the inside ${ }^{6-8}$.

Therefore, The World Health Organization (WHO) recommends that copper concentrations in drinking water not exceed $3.0 \mathrm{mg} \mathrm{L}^{-15}$.

Generally, zinc contamination in drinking water is unlikely, since the concentrations found do not have a toxic effect in the health. However, numerous studies have increasingly exposed that high concentrations of zinc in both groundwater and surface water may exist; and may be intended for human consumption, as it occurs in the north of Chile ${ }^{5}$.

Zinc concentrations higher than $4.0 \mathrm{mg} \mathrm{L}^{-1}$ may cause an astringent and unpleasant taste in drinking water, as well as causing an opaline color and an oily film when it is boiling ${ }^{5}$. Hence, its quantification may be attractive for a portable method of easy identification as proposed in this work.

Undoubtedly, the most used technique for metals determination is atomic absorption spectroscopy (AAS), which is a selective and sensitive technique. Different articles have been published conducting different modifications to improve selectivity and sensitivity, obtaining favorable results ${ }^{9,10}$. In addition to this, inductively coupled plasma atomic emission spectroscopy (ICP-AES) is being quite used for determination of heavy metals due to its high levels of automatization, sensitivity, and multi-analysis. However, these techniques involve a considerable disadvantage due to the high cost and inadequate size for in situ measurements ${ }^{11-13}$.

This is why electrochemical techniques appear as a great alternative for quantification and identification due to its low cost, selectivity, portability, miniaturization, low detection limits, easy sample handling, and speciation ${ }^{14}$.

One of the most commonly used techniques for determining trace metals is by the employment of mercury electrode due to the selectivity, reproducibility, and high sensitivity. Additionally, simultaneous measurements of metals can be conducted ${ }^{15-17}$. Currently, however, that technique is barely used due to mercury toxicity.

Therefore, modified electrodes emerge as an alternative to compensate the disadvantage of that sensor. Thus, several researches have been conducted attempting to replace mercury, this is why bismuth has appeared as an alternative for the determination of metals in surface modification of vitreous carbon. In addition, nanostructured surfaces of bismuth have been developed in order to perform new alternatives of modification which aim at improving the features of such sensor ${ }^{18-22}$.

Screen printed electrodes have also appeared for determination of heavy metals. Thus, screen printed surfaces of carbon nanofiber with silver nanoparticles have appeared as new options for the determination of lead and cadmium.

Studies about the use of screen printed electrodes coupled to nanoscience are emerging as a powerful alternative, because of their low cost as well as being environmentally friendly (low waste). Moreover, it provides us an incredible tool related to the possibility of performing field measurements.

In a similar context, we will study the use of screen printed electrodes of carbon nanotubes $\left(\mathrm{CNT}_{\mathrm{s}}\right)$ with gold nanoparticles $\left(\mathrm{GNT}_{\mathrm{s}}\right)$ for simultaneous determination of zinc, lead, and copper in order to create an affordable, selective, and portable sensor.

\section{EXPERIMENTAL SECTION}

\subsection{Materials and Samples}

All reagents were of analytical grade. The Mili-Q water (Millipore, Bedford, MA) was used for all experiments. The concentrated $\mathrm{HCl}$ used throughout the experiments was p.a., $30 \%$ w/w, d $=1.16 \mathrm{Kg} \mathrm{L}^{-1}$ of Merck or Riedel-de Haën. The standard solutions of lead, zinc, and copper $\left(1000 \mu \mathrm{g} \mathrm{L}^{-1}\right)$ were obtained from Panreac and Fisher Scientific, and diluted according to the necessary work standards. The supporting electrolyte solution was $\mathrm{HCl} 0.1 \mathrm{~mol} \mathrm{~L}^{-1}$.

\subsection{Electrodes and Instrumentation}

Electrochemical measurements were recorded on the Bas $100 \mathrm{~W}$ electrochemical analyzer (Bioanalytical System) attached to a desktop computer using an adequate software (BAS $100 \mathrm{~W} 2.3$ for Windows) in order to control data acquisition and data analysis. 
Screen printed electrodes of $\mathrm{CNT}_{\mathrm{s}}$ modified with $\mathrm{GNP}_{\mathrm{s}}$ were constructed by Dropsens. This sensor consists in 3 electrodes: working electrode, silver reference electrode, and a carbon auxiliary electrode. The dimensions are $3.4 \mathrm{X}$ $1.0 \times 0.03 \mathrm{~cm}$.

\section{RESULTS}

In Figure 1, SEM images of the screen printed electrode surface are shown, which Figure 1 Aa only represents the electrode surface of carbon nanotubes $\left(\mathrm{CNT}_{\mathrm{s}}\right)$ at different dimensions. Figure $1 \mathrm{Bb}$ represents the electrode surface $\mathrm{CNT}_{\mathrm{s}}$ with $\mathrm{GNP}_{\mathrm{s}}$.

Only characteristic filaments of the $\mathrm{CNT}_{\mathrm{s}}$ can be observed in Figure $1 \mathrm{AB}$, and $\mathrm{GNP}_{\mathrm{s}}$ (Figure 1B) are uniformly and entirely distributed on the walls. This is clearly an advantage due to the immense amount of active sites that may interact with the chemical species of interest.

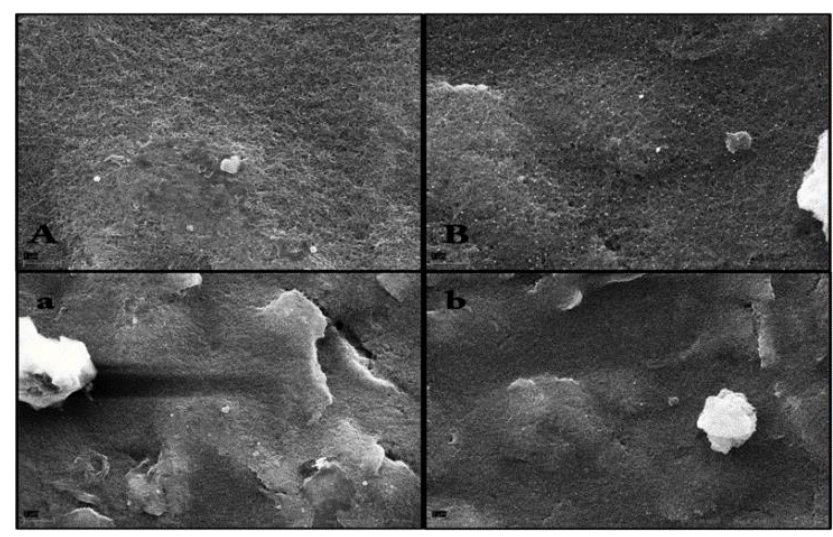

Figure 1. SEM images of the screen printed electrode surface of $\mathrm{CNT}_{\mathrm{s}}$ obtained before $(\mathrm{Aa})$ and after $(\mathrm{Bb}) \mathrm{GNP}_{\mathrm{s}}$ modification.

Although SEM images show the strips of these electrodes revealing a similar distribution between them throughout the surface (images for comparison not shown), an experiment was performed in order to estimate the reproducibility of such sensors. For this purpose, several cyclic voltammetry measurements (CV) in $1 \mathrm{X}^{-3} 0^{-3} \mathrm{~mol} \mathrm{~L}^{-1}$ solution of $\mathrm{Fe}(\mathrm{CN})_{6}{ }^{3-}$ in acetic/acetate buffer $(\mathrm{pH}=4.2)$ were performed. Consequently, cathodic peak area was calculated obtaining a relative standard deviation of $5.95 \%(n=7)$ as observed in Figure 2.

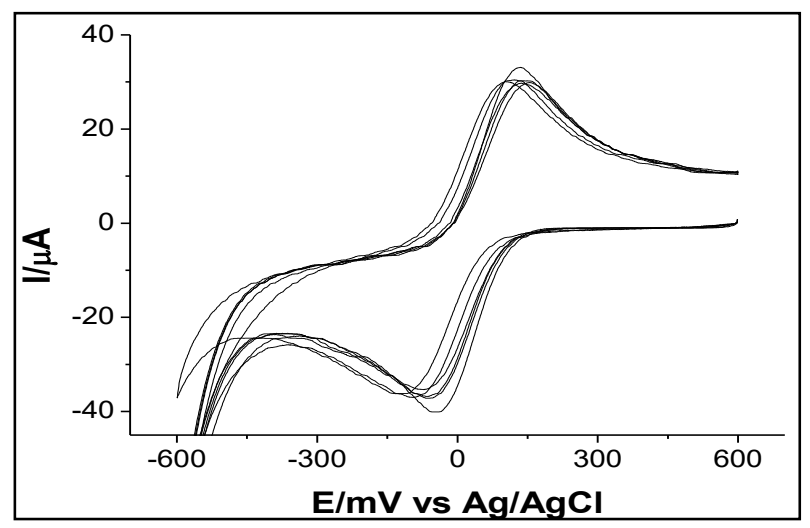

Figure 2. $\mathrm{CV}$ voltammogram in $1 \times 10^{-3} \mathrm{~mol} \mathrm{~L}^{-1}$ solution of $\mathrm{Fe}(\mathrm{CN})_{6}{ }^{3-}$ in acetic/acetate buffer ( $\mathrm{pH}=4.2)$. Sweep rate $100 \mathrm{mV} \mathrm{s}^{-1}$.

The screen printed electrode behavior of $\mathrm{CNT}_{\mathrm{s}}-\mathrm{GNT}_{\mathrm{s}}$ in the presence of zinc, lead, and copper concentrations was investigated. Different voltammograms were performed in a $0.1 \mathrm{~mol} \mathrm{~L}^{-1}$ solution of $\mathrm{HCl}$ in a potential interval of $-0.6 \mathrm{a}$ $0.6 \mathrm{~V}(\mathrm{Ag} / \mathrm{AgCl})$.

As observed in Figure 3, both electrodes are compared $\left(\mathrm{CNT}_{\mathrm{s}}-\mathrm{GNP}_{\mathrm{s}}\right.$ y $\left.\mathrm{CNT}_{\mathrm{s}}\right)$ in a solution containing $100 \mu \mathrm{g} \mathrm{L}^{-1}$ of zinc and lead, and $5.0 \mu \mathrm{g} \mathrm{L}^{-1}$ of copper. Voltammogram $\mathrm{C}$ represents the experiment target which does not emit any current signal. Likewise, the screen printed electrode of $\mathrm{CNT}_{\mathrm{s}}$ obtains a similar signal as the target, a clearly expected behavior of this experiment (Figure 3B).
Voltammogram A (Figure 3) represents the screen printed electrode of $\mathrm{CNT}_{\mathrm{s}}-\mathrm{GNP}_{\mathrm{s}}$, in which 3 current signals (reduction peaks) are observed corresponding to $\mathrm{Zn}^{2+}[\mathrm{I}], \mathrm{Pb}^{2+}[\mathrm{II}]$ and $\mathrm{Cu}^{2+}[\mathrm{III}]$. In all, we can conclude the response to such signals is related to $\mathrm{GNP}_{\mathrm{s}}$ absorbed in the $\mathrm{CNT}_{\mathrm{s}}$.

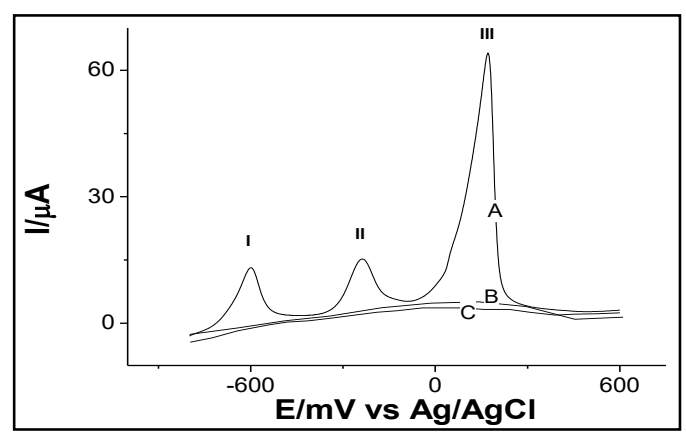

Figure 3. Linear sweep voltammogram in a solution containing $100 \mu \mathrm{g} \mathrm{L}^{-1}$ of zinc and lead, and $5.0 \mu \mathrm{g} \mathrm{L}^{-1}$ of copper, in between $\mathrm{HCl}$ of $0.1 \mathrm{~mol} \mathrm{~L}^{-1}$.

Several experiments of differential pulse anodic stripping voltammetry were performed in order to optimize analytical parameters, and thus obtain major sensitivity. Therefore, it was obtained an accumulation potential of $-1.4 \mathrm{~V}$ $(\mathrm{Ag} / \mathrm{AgCl})$ for the 3 metals, with an accumulation time of $200 \mathrm{~s}$, and scan rate of $100 \mathrm{mV} \mathrm{s}^{-1}$ (Figure 4).
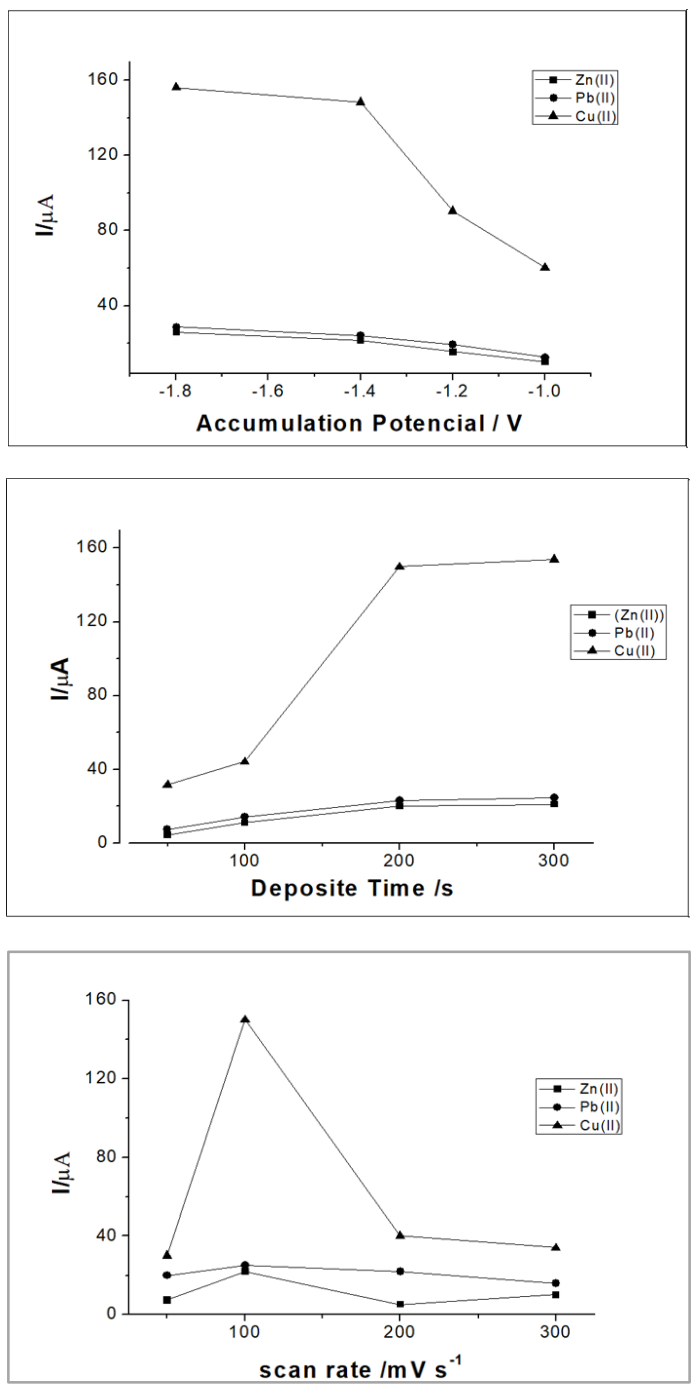

Figure 4. Optimization of analytical parameters: accumulation potential, deposition time, and scan rate. The current signals were dependent on the different concentration of zinc, lead, and copper. 
The relation between the current signal and the concentration of zinc and lead was studied in a range of 9.9 to $120 \mu \mathrm{g} \mathrm{L}^{-1}$, and in a range of 0.99 to $12 \mu \mathrm{g} \mathrm{L}^{-1}$ for the copper respectively. The use of optimal conditions produced linear responses for the 3 metals: $-\operatorname{Ip}(\mathrm{A})=0.08+0.214\left[\mathrm{Zn}^{2+}\left(\mu \mathrm{g} \mathrm{L}^{-1}\right)\right], \mathrm{R}^{2}=0.993$; $-\mathrm{Ip}(\mathrm{A})=-1.06+0.240\left[\mathrm{~Pb}^{2+}\left(\mu \mathrm{g} \mathrm{L}^{-1}\right)\right], \mathrm{R}^{2}=0.988 ;-\operatorname{Ip}(\mathrm{A})=-10.93+15.16\left[\mathrm{Cu}^{2+}\right.$ $(\mu \mathrm{g} \mathrm{L}-1)], \mathrm{R}^{2}=0.988$. Detection limits $(3 \mathrm{SD})$ and quantification $(10 \mathrm{SD})$ were estimated between $1.0-3.5 \mu \mathrm{g} \mathrm{L}{ }^{-1}$ for $\mathrm{Zn}^{2+}, 1.5-5.0 \mu \mathrm{g} \mathrm{L}^{-1}$ for $\mathrm{Pb}^{2+}$, and 0.1 $-0.33 \mu \mathrm{g} \mathrm{L}^{-1}$ for $\mathrm{Cu}^{2+}$ (Figure 5).

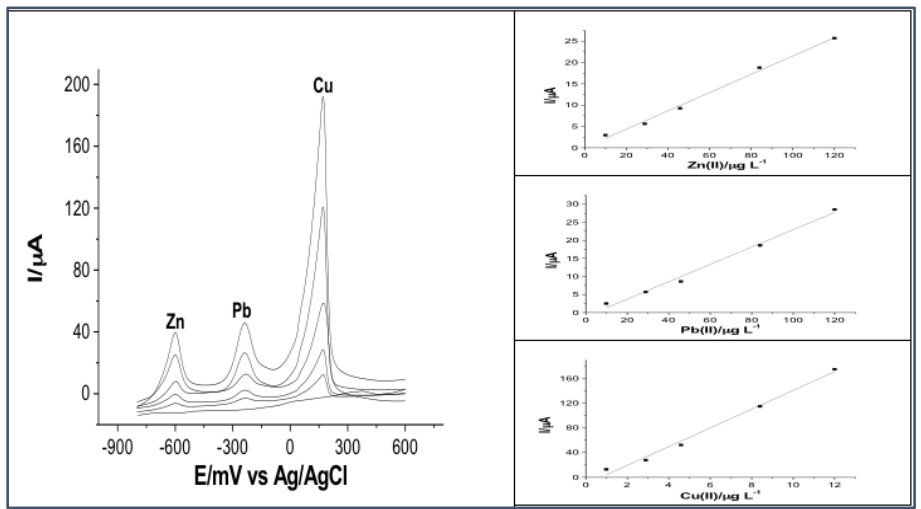

Figure 5. Voltammogram after successive additions of zinc, lead and copper, and the analytical curves.

\section{CONCLUSIONS}

This work reveals the use of a screen printed electrode of carbon nanotubes modified with gold nanoparticles for determination of zinc, lead and copper respectively. Experimental conditions indicate the simplicity of quantification and use of the same procedures for the 3 metals. Besides, the scant amount of samples without separation and extraction stages must be highlighted. This is of utmost importance because there is a decrease in contamination risks of sampling or alteration problems on the present chemical species.

LSASV technique was performed providing a sensitive sensor and low detection limits for determination of such metals.

This is an attractive sensor since it may be easily transported permitting in situ measurements and decision-making capacity in real time.

Due to the affordability and unique characteristic of determining more than one species at the same time, this sensor appears as a major possibility for the use in environmental impact assessment, toxicological evaluations regarding to drinking water or permitting the study of the behavior of these metals within an aquatic environment.

\section{REFERENCES}

1. Behrman R.E. "Textoook of Pediatrics" 14 Ed., W.B. Saunders Company, Philadelphia, EE.UU, 1992, p. 1788-17791.

2. Agency of Toxic Substances and Disease Registry. Case studies in environmental medicine. Lead toxicity. US Department of Health and Human Services, Public Health Service. Atlanta, GA: The Agency.

3. Budd P, Montgomery J, Cox A, Krause P, Barreiro B, Thomas R.G. The distribution of lead within ancient and modern human teeth: implications for long-term and historical exposure monitorin. Sci Total Environ. 1998, Vol. 220, p. 121-136.

4. Lanphear B.P., Matte T.D., Rogers J., Cickner R.P.; Dietz B.; Bornschein R.L., et al. The contribution of lead-contaminated house dust and residential soil to children's blood lead levels. A pooled analysis of 12 epidemiologic studies. Environ Res. 1998, Vol. 79, p. 51-68.

5. Guidelines for drinking wáter quality third edition, volumen 1. World health Organization.

6. Malvankar P.L., Shinde V.M. Analyst. 10, 1081-1084, (1991).

7. Aitio A., Aro A. Jarvisalo J., Vainio H. Cambridge the royal society of chemistry 125, 141-155, (1991).

8. Pellerano R.G., Romero C.H., Acevedo H.A. y Vázquez F.A. Quim. Nova. 30, 2020-2024, (2007).

9. Blanco Hernández A.L., Alonso Gutiérrez D., Jiménez de Blas O., Santiago Guervós M., Manzano B. Rev Esp Salud Pública. 72, 53-65, (1998).

10. Viñas P., López-García I., Lanzón M. and Hernández-Córdoba M. J. Agric. Food Chem. 45, 3952-3956, (1997).
11. Mykytiuk A.P., Russell D.S. and Sturgeon R.E. Analytical chemistry. 52, 1281-1283, (1998).

12. Leermakers M., Baeyens W., Gieter M.D., Smedts B., Meert C., De Bisschop H.C., Morabito R., Quevauviller P. Trends Anal Chem. 25, 1-10, (2006).

13. Hung D.Q., Nekrassova O., Compton R.G. Talanta. 64, 269-277, (2004).

14. Gamboa J.C.M., Peña R.C., Paixão T.R.L.C., Bertotti M. Talanta. 80, 581$585,(2009)$

15. Hawkings R.C. and Thode H.G. 16, 71-74, (1944).

16. Barra C.M., Dos Santos M.M.C. Electroanalysis. 13, 1098-1104, (2001).

17. Greulach U., Henze G. Anal Chim Acta . 306, 217-223, (1995).

18. Wang J., Lu J., Hocevar S.B., Farias PAM and Ogorevc B. Analytical Chemistry. 72, 3218-3222, (2000).

19. Economou A. Trends in Analytical Chemistry. 24, 334-340, (2005).

20. Charalambous A. and Economou A. Analytica Chimica Acta. 547, 53-58, (2005).

21. Guo Z., Feng F., Hou Y. and Jaffrezic-Renault N. Talanta. 65, 1052-1055, (2005).

22. Tarasova V.A. Journal of Analytical Chemistry. 62 (2), 157-160, (2007) 